\title{
Gambaran Drug Related Problems (DRP's) pada Penatalaksanaan Pasien Stroke Hemoragik dan Stroke Non Hemoragik di RSUD Dr M Yunus Bengkulu
}

Dian Handayani*, Dwi Dominica

Program Studi Farmasi, Fakultas MIPA, Universitas Bengkulu, Bengkulu

*Corresponding author: dhandayani@unib.ac.id

\begin{abstract}
Background: Stroke is a cerebrovascular disease that is a major cause of death occurs in Indonesia. The number of stroke sufferers around the world under 45 years continues to increase. The presence of comorbidities and various risk factors for patients will be more likely to consume more than two types of drugs and to get the risk of drug related problems (DRPS). Objective: This study aimed to identify the type of incidences of DRP's in stroke patients who are undergoing treatment at a neurosurgery clinic at Dr. M Yunus Bengkulu Public Hospital. Methods: This study was conducted with a cross sectional and prospective method for neuropathic outpatients for 2 months. Subjects who met the inclusion criteria for all 89 patients. Exclusion criteria were patients who did not agree for research and were deaf. Data collection was done by conducting interviews and filling out the quality of life questionnaire using the Short Form 36 (SF-36). Results: Eighty nine stroke patients as many as 85 patients (95.5\%) had a non-hemorrhagic stroke, the incidence of drug related problems (DRP) in stroke patients at outpatient polyclinic of Dr. M Yunus Bengkulu Hospital: 20 untreated cases (22.5\%), unnecessary drugs as many as 3 cases (3.4\%), drug side effects were 4 cases (4.5\%), and the number of drugs that were not exact were 4 cases (4.5\%). There is no relationship between factors and the number of drugs associated with drug related problems (DRP's), there is a relationship between the quality of life of stroke patients with drug related problems (DRP) in the physical domain. Conclusion: The most type of stroke common in hospital is non hemorragical many as 85 cases (95.5\%). The incident of drug related problems (DRP's) in patients of stroke in hospital as many as 31 incidents. The type of drug related problems (DRP's) occured such as indication without drug treatment as many as 20 patients (22.5\%), drug without indication as many as 3 cases (3.4\%), adverse drug reaction as many as 4 cases (4.5\%), dan drug wrong as many as 4 cases (4.5\%). There is no relationship between the risk factors age and number of drugs received and patients with incidents of drug related problems (DRP's). There is a relationship between the quality of life of stroke patients and drug related problems (DRP's) on domain physical condition.
\end{abstract}

Keywords: drug related problems, RSUD Dr M Yunus Hospital Bengkulu, stroke, SF-36

\begin{abstract}
Abstrak
Pendahuluan: Stroke merupakan penyakit serebrovaskular yang menjadi penyebab utama kematian yang sering terjadi di Indonesia. Jumlah penderita stroke di seluruh dunia yang berusia dibawah 45 tahun terus meningkat. Adanya penyakit penyerta serta berbagai faktor resiko pasien stroke mengakibatkan pasien akan sering mengkonsumsi lebih dari dua macam obat dan dapat berisiko pada ketidakefektifan pengobatan dan memungkinkan terjadi drug related problems (DRPs). Tujuan: Penelitian ini bertujuan untuk mengetahui gambaran kejadian DRPs pada pasien stroke yang menjalani pengobatan di poli saraf RSUD Dr M Yunus Bengkulu. Metode: Penelitian ini dilakukan dengan metode cross sectional secara prospektif pada pasien rawat jalan di poli saraf selama 2 bulan. Subjek yang memenuhi kriteria inklusi sejumlah 89 pasien. Kriteria eksklusi adalah pasien yang tidak bersedia terlibat hingga akhir penelitian dan tuli. Pengumpulan data dilakukan dengan melakukan wawancara dan pengisian kuesioner kualitas hidup menggunakan Short Form 36 (SF-36). Hasil: Dari 89 pasien stroke sebanyak 85 pasien $(95,5 \%)$ menderita stroke non hemoragik, kejadian drug related problems (DRP's) pada pasien stroke di poliklinik rawat jalan RSUD Dr M Yunus Bengkulu meliputi: ada indikasi yang tidak diterapi sebanyak 20 kasus (22,5\%), obat yang tidak diperlukan sebanyak 3 kasus $(3,4 \%)$, efek samping obat sebanyak 4 kasus (4,5\%), dan pemilihan obat yang tidak tepat sebanyak 4 kasus $(4,5 \%)$. Tidak ada hubungan antara faktor risiko umur dan jumlah obat yang diterima pasien dengan kejadian drug related problems
\end{abstract}


(DRP's), ada hubungan antara kualitas hidup pasien stroke dengan drug related problems (DRP's) pada domain keadaan fisik. Kesimpulan: Jenis stroke yang paling banyak terjadi di RSUD Dr M Yunus Bengkulu adalah stroke non hemoragik sebanyak 85 pasien (95,5\%). Kejadian drug related problems (DRP's) pada pasien stroke di poliklinik rawat jalan RSUD Dr M Yunus Bengkulu terjadi sebesar 31 kasus. Jenis drug related problems (DRP's) yang terjadi meliputi ada indikasi yang tidak diterapi sebanyak 20 kasus (22,5\%), ada obat yang tidak perlu sebanyak 3 kasus $(3,4 \%)$, efek samping obat sebanyak 4 kasus $(4,5 \%)$, dan pemilihan obat yang tidak tepat sebanyak 4 kasus $(4,5 \%)$. Tidak ada hubungan antara faktor risiko umur dan jumlah obat yang diterima pasien dengan kejadian drug related problems (DRP's). Terdapat hubungan antara kualitas hidup pasien stroke dengan drug related problems (DRP's) pada domain keadaan fisik.

Kata kunci: drug related problems, RSUD Dr M Yunus Bengkulu, stroke, SF-36

\section{PENDAHULUAN}

Stroke merupakan penyakit serebrovaskular yang menjadi penyebab utama kematian di Indonesia. Jumlah penderita stroke di seluruh dunia yang berusia dibawah 45 tahun terus meningkat. Badan Kematian akibat stroke diprediksi akan meningkat seiring dengan kematian akibat penyakit jantung dan kanker. Stroke merupakan penyebab kematian tersering ketiga di Amerika dan merupakan penyebab utama disabilitas permanen (Yunaidi, 2010).

Stroke dibagi menjadi 2, yaitu stroke hemoragik dan stroke non hemoragik. Diperkirakan stroke non hemoragik (iskemik) mencapai 85\% dari jumlah stroke yang terjadi. Tujuan utama penatalaksanaan pasien stroke meliputi tiga hal, yaitu mengurangi kerusakan neurologik lebih lanjut, menurunkan angka kematian dan ketidakmampuan gerak pasien (immobility) dan kerusakan neurologik serta mencegah serangan berulang (kambuh). Kebanyakan pasien stroke menerima obat polifarmasi karena sebagian besar pasien stroke mengalami komplikasi. Untuk mendapatkan outcome terapi yang baik pada pasien stroke yang menjalani pengobatan diperlukan kerjasama multidisiplin ilmu antara dokter, perawat, farmasis dan tenaga kesehatan lain, bahkan keluarga pasien (Fagan \& Hess, 2005).

Drug related problems (DRP's) merupakan masalah kesehatan yang serius yang dapat terjadi pada semua tingkat umur, dapat mempengaruhi kualitas hidup pasien serta menimbulkan dampak ekonomi yang cukup besar. Besdine dkk. (2003) melaporkan bahwa berdasarkan meta analisis dari 39 studi perspektif pada bulan April 1998, dalam satu tahun terdapat sekitar 2.216 .000 pasien yang dirawat di rumah sakit akibat mengalami Adverse Drug Reactions (ADRs) yang serius dan 106.000 pasien meninggal karena masalah-masalah terkait obat. Dilihat dari segi ekonomi, DRPs merupakan permasalahan yang memiliki dampak ekonomi sangat besar. Dampak ekonomi terkait DRPs yang terjadi pada semua umur baik di rumah sakit, rumah perawatan (nursing home), maupun komunitas, sementara biaya langsung terkait DRPs di rumah sakit dan rumah perawatan masingmasing sebesar \$4 milyar (Besdine dkk., 2003).

Penyakit stroke mempunyai dampak yang besar terhadap kualitas hidup pasien. Menurut World Health Organization (WHO), kualitas hidup adalah persepsi individu dimana posisi mereka dalam kehidupan mencakup konteks sistem budaya dan nilai dimana kehidupannya berkaitan dengan tujuan, harapan, standar, dan kekhawatiran. Untuk mengukur kualitas hidup pasien stroke digunakan kuesioner SF-36 yang sudah divalidasi dan ditranslasi dalam versi Indonesia yang digunakan sebagai gold standart untuk kuesioner EORTC (Perwitasari dkk., 2010) karena instrumen SF-36 dapat digunakan untuk menilai dan membandingkan kondisi kesehatan pasien pada berbagai macam penyakit baik penyakit umum maupun penyakit kronis, karena stroke merupakan salah satu penyakit kronis maka dapat digunakan kuesioner SF-36 untuk mengukur kualitas hidup pasien stroke.

Berdasarkan pertimbangan di atas penelitian ini dilakukan untuk mengetahui gambaran drug related problems (DRP's) pada penatalaksanaan pasien stroke di RSUD Dr M Yunus Bengkulu. Penelitian ini diharapkan dapat memberikan sumbangan pengetahuan bagi tenaga kesehatan untuk meningkatkan pelayanan kefarmasian terhadap pasien.

\section{METODE}

Penelitian ini merupakan jenis penelitian observasional yang didesain secara cross sectional dengan pengambilan data secara prospektif. Penelitian dilakukan di RSUD Dr M Yunus Bengkulu selama 2 bulan pada pasien stroke baik hemoragi dan stroke non hemoragik dengan kriteria inklusi: (1) Pasien rawat 
jalan yang menjalani pengobatan di poli saraf RSUD Dr M Yunus Bengkulu, (2) Laki-laki dan perempuan, (3) Menderita stroke hemoragik atau stroke non hemoragik, (4) Geriatri ( $\geq 60$ tahun) atau non geriatri ( $\leq 60$ tahun), (5) Dengan atau tanpa komplikasi, (6) Pasien dalam keadaan sadar, (7) Bersedia menjadi responden. Sedangkan kriteria ekslusi pada penelitian ini adalah tuli dna tidak bersedia terlibat menjadi responden hingga akhir penelitian.

Diawal penelitian diperlukan ethical clearance dari komite etik, identifikasi jumlah populasi pasien stroke yang menjalani pengobatan di poli saraf RSUD Dr M Yunus Bengkulu dan validasi kuesioner yang digunakan. Langkah-langkah yang dilakukan peneliti dalam menjalankan penelitian ini addalah sebagai berikut: (1) Memilih pasien terdiagnosa stroke yang termasuk dalam kriteria inklusi, (2) Rekrutmen pasien dengan cara mengisi dan menandatangai lembar informed consent, lembar pencatatan data, lembar penilaian kesehatan (data demografi pasien), (3) Mewawancarai pasien untuk konfirmasi riwayat medik yang tertulis dalam kuesioner, termasuk diminta melengkapi lembar kuesioner kepatuhan menggunakan kuesioner SF-36. Responden yang didapatkan pada penelitian ini sebesar 89 pasien. Hasil wawancara dengan kuesiner SF-36 dianalisis menggunakan program SPSS.
Untuk melihat gambaran drug related problems (DRP's) dilakukan analisis menggunakan uji chi square dan gambaran kualitas hidup pasien stroke menggunakan uji indepandent $t$-Test.

\section{HASIL DAN PEMBAHASAN}

Pasien yang mengikuti penelitian ini sebanyak 89 pasien. Usia pasien lebih didominasi oleh pasien yang berumur kurang dari 60 tahun sebanyak 64 pasien $(71,9 \%)$, sedangkan yang berusia lebih dari 60 tahun sebanyak 25 pasien $(28,1 \%)$. Responden yang menderita stroke dengan jenis kelamin laki-laki sebanyak 59 pasien $(66,3 \%)$ sedangkan perempuan sebanyak 30 pasien $(33,7 \%)$. Responden yang memiliki tingkat pendidikan rendah (tidak sekolah, SD, SMP SMA) ada 64 responden $(71,9 \%)$ sementara responden dengan pendidikan tinggi (D1, D3, S1, S2) sebanyak 25 pasien $(28,1 \%)$. Pada kategori tingkat pekerjaan tinggi (swasta, wiraswasta, PNS) sebanyak 33 pasien $(37,1 \%)$ dan responden dengan jenis pekerjaan rendah (tidak bekerja, buruh, pedagang) sebanyak 56 pasien $(62,9 \%)$. Untuk jenis stroke didominasi oleh stroke non hemoragik sebanyak 85 pasien $(95,5 \%)$ dan stroke hemoragik sebanyak 4 pasien $(4,5 \%)$, seperti terlihat pada Tabel 1 .

Tabel 1. Data demografi pasien stroke rawat jalan RSUD Dr M Yunus Bengkulu

\begin{tabular}{|c|c|c|c|}
\hline Variabel & Kategori & $\mathrm{N}$ & $\%$ \\
\hline \multirow[t]{3}{*}{ Usia } & $<60$ tahun & 64 & 71,9 \\
\hline & $>60$ tahun & 25 & 28,1 \\
\hline & Total & 89 & 100 \\
\hline \multirow[t]{3}{*}{ Jenis Kelamin } & Laki-laki & 59 & 66,3 \\
\hline & Perempuan & 30 & 33,7 \\
\hline & Total & 89 & 100 \\
\hline \multirow[t]{3}{*}{ Pendidikan } & Rendah (Tidak sekolah, SD, SMP, SMA) & 64 & 71,9 \\
\hline & Tinggi ( D1, D2, D3, S1, S2) & 25 & 28,1 \\
\hline & Total & 89 & 100 \\
\hline \multirow[t]{3}{*}{ Pekerjaan } & Rendah (Tidak bekerja, buruh, pedagang) & 33 & 37,1 \\
\hline & Tinggi (PNS, swasta, wiraswasta) & 56 & 62,9 \\
\hline & Total & 89 & 100 \\
\hline \multirow[t]{3}{*}{ Jenis Stroke } & Stroke Non Hemoragik & 85 & 95,5 \\
\hline & Stroke Hemoragik & 4 & 4,5 \\
\hline & Total & 89 & 100 \\
\hline
\end{tabular}

Karakteristik responden juga dapat dilihat klinis pasien berdasarkan pengobatan yang diperoleh saat menjalani pengobatan. Pasca stroke yang dapat dijabarkan dalam Tabel 2 meliputi golongan obat seperti antihipertensi, anti platelet, dan neuroprotektor.
Golongan antihipertensi adalah amlodipin $5 \mathrm{mg}$ sebanyak 52 pasien $(58,4 \%)$, amlodipin $10 \mathrm{mg}$ sebanyak 34 pasien $(38,2 \%)$, golongan beta blocker seperti bisoprolol sebanyak 2 pasien $(2,2 \%)$, dan tanpa antihipertensi sebanyak 1 pasien $(1,1 \%)$ Penggunaan 
obat stroke golongan antipaltelet yang paling banyak adalah aspilet sebanyak 37 pasien $(41,6 \%)$ sedangkan yang mendapat clopidogrel sebanyak 35 pasien $(39,3 \%)$, dan tanpa pemberian antiplatelet sebanyak 17 pasien (19,1\%). Golongan neuroprotektor yang digunakan adalah pirasetam sebanyak 48 pasien (53,9\%), citicolin sebanyak 8 pasien $(9,0 \%)$, kortikosteroid sebanyak 4 pasien $(4,5 \%)$, calcium channal blocker sebanyak 15 pasien $(16,9 \%)$ dan tanpa pemberian neuroprotektor sebanyak 14 pasien $(15,7 \%)$.

Tabel 2. Karakteristik klinis pasien stroke rawat jalan RSUD Dr M Yunus Bengkulu

\begin{tabular}{|c|c|c|}
\hline Karakteristik Klinis & $\mathrm{N}$ & $\%$ \\
\hline \multicolumn{3}{|l|}{ Jenis terapi obat Antihipertensi } \\
\hline Amlodipin $5 \mathrm{mg}$ & 52 & 58,4 \\
\hline Amlodipin $10 \mathrm{mg}$ & 34 & 38,2 \\
\hline Bisoprolol & 2 & 2,2 \\
\hline \multirow[t]{2}{*}{ Tanpa Antihipertensi } & 1 & 1,1 \\
\hline & 89 & 100 \\
\hline \multicolumn{3}{|l|}{ Antiplatelet } \\
\hline Asetosal & 37 & 41,6 \\
\hline Clopidogrel & 35 & 39,3 \\
\hline Tanpa Antiplatelet & 17 & 19,1 \\
\hline Total & 89 & 100 \\
\hline \multicolumn{3}{|l|}{ Neuroprotektor } \\
\hline Pirasetam & 48 & 53,9 \\
\hline Citicolin & 8 & 9,0 \\
\hline Kortikosteroid & 4 & 4,5 \\
\hline CCB (Calcium Channal Blocker) & 15 & 16,9 \\
\hline Tanpa Neuroprotektor & 14 & 15,7 \\
\hline Total & 89 & 100 \\
\hline
\end{tabular}

Kejadian DRP pada pasien stroke di poliklinik rawat jalan RSUD Dr M Yunus Bengkulu terjadi sebesar 31 kasus. Pasien yang tidak mengalami DRP sebanyak 58 pasien. Kejadian DRP pada masingmasing jenis DRP akan dijelaskan pada Tabel 3 berikut.

Tabel 3. Persentase jenis kejadian DRP

\begin{tabular}{lcc}
\hline \multicolumn{1}{c}{ Jenis DRP } & $\mathrm{N}$ & $\%$ \\
\hline Tidak terjadi DRP & 58 & 65,2 \\
Ada indikasi yang tidak diterapi & 20 & 22,5 \\
Ada obat yang tidak perlu & 3 & 3,4 \\
Efek samping & 4 & 4,5 \\
Pemilihan obat yang tidak tepat & 4 & 4,5 \\
\hline Total & 89 & 100 \\
\hline
\end{tabular}

Kejadian DRP pada kategori ada indikasi yang tidak diterapi terjadi pada 20 pasien $(65,2 \%)$. Penggunaan obat yang tidak diperlukan terdapat 3 kasus $(3,4 \%)$, kejadian efek samping obat ada 4 kasus $(4,5 \%)$, dan pemilihan obat yang tidak tepat sebanyak 4 kasus $(4,5 \%)$.

Faktor risiko yang menjadi penyebab timbulnya drug related problems adalah faktor usia dan jumlah obat yang diterima pasien. Pasien geriatri sebagai faktor risiko positif dan pasien non geriatri sebagai faktor risiko negatif. Jumlah obat yang diberikan > 3 macam dikategorikan sebagai faktor risiko positif dan jumlah obat yang diberikan $\leq 3$ macam dikategorikan sebagai faktor risiko negatif. Penjelasan mengenai hubungan faktor resiko dengan kejadian DRP akan dijelaskan pada Tabel 4 berikut. 
Tabel 4. Hubungan faktor risiko dengan kejadian DRP

\begin{tabular}{|c|c|c|c|c|c|}
\hline \multirow{2}{*}{ Usia } & \multicolumn{2}{|c|}{ Kejadian DRP } & \multirow[b]{2}{*}{$p$} & \multirow{2}{*}{ OR } & \multirow{2}{*}{ CI $95 \%$} \\
\hline & Terjadi & Tidak Terjadi & & & \\
\hline$>60$ tahun & 7 & 18 & \multirow{2}{*}{0,377} & \multirow{2}{*}{1,347} & \multirow{2}{*}{$0,489-3,713$} \\
\hline$\leq 60$ tahun & 22 & 42 & & & \\
\hline \multirow{2}{*}{ Jumlah Obat } & \multicolumn{2}{|c|}{ Kejadian DRP } & \multirow[b]{2}{*}{$p$} & \multirow{2}{*}{ OR } & \multirow{2}{*}{ CI $95 \%$} \\
\hline & Terjadi & Tidak Terjadi & & & \\
\hline$>3$ & 28 & 1 & \multirow{2}{*}{0,472} & \multirow{2}{*}{2,00} & \multirow{2}{*}{$0,213-18,745$} \\
\hline$\leq 3$ & 56 & 4 & & & \\
\hline
\end{tabular}

Pada Tabel 5 ditampilkan jawaban pertanyaan pasien dari no 1 sampai no 36 pada SF-36 dikelompokkan menjadi domain kesehatan umum, fungsi fisik, keadaan fisik, keadaan emosional, fungsi sosial, nyeri tubuh, kesehatan mental, dan vitalitas. Domain-domain tersebut dianalisis secara deskriptif.
Rata-rata domain fungsi kuesioner SF-36 menunjukkan kedelapan domain fungsi SF-36 memiliki signifikansi p > 0,05 ini menunjukkan data terdistribusi normal dan berupa data parametrik, sehingga pada analisis statistik menggunakan Independent T-test dengan tingkat kepercayaan $95 \%$.

Tabel 5. Rata-rata domain fungsi kuesioner SF-36

\begin{tabular}{ccc}
\hline Domain Fungsi & Rata-rata \pm SD & $p$ \\
\hline Kesehatan Umum (KU) & $77,96 \pm 5,84$ & 0,001 \\
Fungsi Fisik (FF) & $79,96 \pm 1,39$ & 0,000 \\
Keadaan Fisik (KF) & $66,55 \pm 1,51$ & 0,004 \\
Keadaan Emosional (KE) & $53,55 \pm 1,85$ & 0,000 \\
Fungsi Sosial (FS) & $60,73 \pm 1,77$ & 0,000 \\
Nyeri Tubuh (NT) & $72,48 \pm 2,16$ & 0,000 \\
Vitalitas (V) & $73,37 \pm 1,03$ & 0,003 \\
Kesehatan Mental (KM) & $76,31 \pm 1,38$ & 0,053 \\
\hline
\end{tabular}

*Data terdistribusi normal

Hasil penelitian (Tabel 6) menunjukkan bahwa kedelapan domain baik kesehatan umum, fungsi fisik, keadaan fisik, keadaan emosional, fungsi sosial, nyeri tubuh, vitalitas, dan keadaan mental memberikan hasil yang tidak berbeda signifikan $(\mathrm{p}>0,05)$ terhadap drug related problems (DRP's). Hal ini dapat disimpulkan bahwa drug related problems (DRP's) tidak berpengaruh terhadap kualitas hidup pasien stroke yang menjalani pengobatan di poliklinik rawat jalan RSUD Dr M Yunus Bengkulu. 
Tabel 6. Hubungan kualitas hidup dengan DRP

\begin{tabular}{|c|c|c|c|c|}
\hline Domain Fungsi & $\begin{array}{c}\text { Drug Related Problems } \\
\text { (DRP's) }\end{array}$ & Rata-rata \pm SD & $p$ & Signifikasi \\
\hline Kesehatan Umum (KU) & $\begin{array}{c}\text { Terjadi DRP } \\
\text { Tidak terjadi DRP }\end{array}$ & $76,84 \pm 5,84$ & 0,208 & Tidak Signifikan \\
\hline Fungsi Fisik (FF) & $\begin{array}{c}\text { Terjadi DRP } \\
\text { Tidak terjadi DRP }\end{array}$ & $74,38 \pm 17,34$ & 0,229 & Tidak Signifikan \\
\hline Keadaan Fisik (KF) & $\begin{array}{c}\text { Terjadi DRP } \\
\text { Tidak terjadi DRP }\end{array}$ & $61,20 \pm 16,85$ & 0,019 & Signifikan \\
\hline Keadaan Emosional (KE) & $\begin{array}{c}\text { Terjadi DRP } \\
\text { Tidak terjadi DRP }\end{array}$ & $51,72 \pm 19,08$ & 0,520 & Tidak Signifikan \\
\hline Fungsi Sosial (FS) & $\begin{array}{c}\text { Terjadi DRP } \\
\text { Tidak terjadi DRP }\end{array}$ & $58,87 \pm 15,77$ & 0,496 & Tidak Signifikan \\
\hline Nyeri Tubuh (NT) & $\begin{array}{c}\text { Terjadi DRP } \\
\text { Tidak terjadi DRP }\end{array}$ & $75,56 \pm 18,42$ & 0,354 & Tidak Signifikan \\
\hline Vitalitas (V) & $\begin{array}{c}\text { Terjadi DRP } \\
\text { Tidak terjadi DRP }\end{array}$ & $72,93 \pm 8,07$ & 0,782 & Tidak Signifikan \\
\hline Kesehatan Mental (KM) & $\begin{array}{c}\text { Terjadi DRP } \\
\text { Tidak terjadi DRP }\end{array}$ & $73 ., 51 \pm 12,34$ & 0,188 & Tidak Signifikan \\
\hline
\end{tabular}

\section{PEMBAHASAN}

Penelitian ini dilakukan di Poliklinik Rawat Jalan RSUD Dr M Yunus Bengkulu selama dua bulan. Jumlah sampel yang memenuhi kriteria inklusi sebanyak 89 pasien. Berdasarkan karakteristik responden usia pasien yang menderita stroke di RSUD Dr M Yunus Bengkulu sebagian besar terjadi pada kelompok usia kurang dari 60 tahun yaitu sebesar 64 pasien $(71,9 \%)$. Dan pada kelompok usia lebih dari 60 tahun sebesar 25 pasien $(28,1 \%)$. Namun, lain halnya dengan penelitian yang dilakukan oleh Rahajeng (2007) bahwa sebagian besar penderita stroke berada pada kelompok usia lebih dari 60 tahun. Menurut Goldstein dkk. (2006) bahwa risiko terkena stroke meningkat dua kali lipat pada usia lebih dari 55 tahun. Penelitian WHO MONICA menunjukkan bahwa insidensi stroke bervariasi antara $48-240$ per 100.000 per tahun pada usia 45 - 54 tahun. Sementara di Amerika Serikat menunjukkan angka 113,8 kasus stroke per 100.000 orang pertahun pada usia kurang dari 55 tahun.

Sebagian besar pasien yang menderita stroke adalah responden dengan jenis kelamin laki-laki yaitu sebesar 59 pasien $(66,3 \%)$. Sedangkan responden dengan jenis kelamin perempuan sebesar 30 pasien $(33,7 \%)$. Berdasarkan faktor risiko, laki-laki lebih tinggi mendapat serangan stroke dibanding perempuan. Hal ini dapat disebabkan karena pola gaya hidup seperti merokok yang dapat terjadi penyumbatan di pembuluh darah. Selain itu, prevalensi merokok di Indonesia pada 2012 diketahui bahwa pria Indonesia yang digolongkan perokok aktif lebih besar dibandingkan perempuan (Indriani, 2014). Para riset di University of California, menemukan bahwa hormon estrogen pada perempuan dapat menjaga pembuluh darah di otak tetap sehat dengan meningkatkan efisiensi mitokondria dalam pembuluh darah otak (Brizendine, 2006).

Jenis stroke yang terjadi adalah stroke non hemoragik 85 pasien $(95,5 \%)$ dan stroke hemoragik 4 orang $(4,5 \%)$. Pada beberapa negara di dunia, penderita stroke memiliki komposisi $70 \%$ stroke iskemik, $27 \%$ stroke hemoragik dan 3\% stroke dengan sebab yang tidak diketahui. Jumlah stroke hemoragik di Cina berkisar 17,1 - 39,4\%, di Jepang sampai 38,7\% (Yuliana dkk., 2011).

Kejadian stroke iskemik lebih banyak terjadi dibandingkan stroke hemoragik. Penelitian Dinata dkk. (2013) menemukan bahwa empat faktor risiko tertinggi yang berkontribusi terhadap munculnya stroke iskemik diantaranya adalah usia lebih dari 50 tahun $(45,83 \%)$ dan kolesterol total meningkat $(45,83 \%)$ yang mempengaruhi penyempitan pada pembuluh darah, gula darah meningkat $(47,89 \%)$ yang mempengaruhi viskositas darah yang semakin meningkat, dan hipertensi $(43,76 \%)$ yang mempengaruhi tekanan perfusi otak. Faktor risiko ini berkontribusi terhadap penurunan suplai oksigen melalui aliran darah ke otak yang dapat menimbulkan stroke iskemik.

Berdasarkan karakteristik klinis pasien dalam penelitian ini paling banyak penggunaan obat stroke pada golongan antihipertensi adalah amlodipin $10 \mathrm{mg}$ sebanyak 34 pasien $(38,2 \%)$, amlodipin $5 \mathrm{mg}$ sebanyak 52 pasien $(58,4 \%)$, golongan beta blocker seperti bisoprolol sebanyak 2 pasien $(2,2 \%)$, dan tanpa antihipertensi ada 1 pasien $(1,1 \%)$. Penggunaan obat antihipertensi bertujuan untuk menurunkan tekanan darah pada pasien stroke setelah periode akut terlewati 
(setelah 7 hari) (Chobanian dkk., 2004; Fagan \& Hess, 2005). Target penurunan tekanan darah tersebut adalah 15 - 25\% pada jam pertama dan tekanan darah sistolik 160/90 mmHg dalam 6 jam pertama. Pada stroke iskemik akut, hipertensi yang tidak dikelola dengan baik dapat berakibat meluasnya area infark, edema serebral serta transformasi perdarahan, sedangkan pada stroke hemoragik, hipertensi dapat mengakibatkan perdarahan ulang dan semakin meluasnya perdarahan. Penurunan tekanan darah pada stroke fase akut harus dilakukan dengan hati-hati. Penurunan tekanan darah yang terjadi dengan cepat dapat mengakibatkan kerusakan organ semakin parah dan memperburuk kondisi klinis neurologik pasien (Soenarta dkk, 2015).

Penggunaan obat golongan antiplatelet yang paling banyak adalah clopidogrel sebanyak 35 pasien (39,3\%) sedangkan yang mendapat asetosal sebanyak 37 pasien (41,6\%), dan tanpa pemberian antiplatelet sebanyak 17 pasien $(19,1 \%)$. Clopidogrel merupakan tienopiridin dengan efek samping yang lebih rendah. Dosis lazim $75 \mathrm{mg} / \mathrm{hari}$ memiliki efikasi yang sama dengan aspirin $325 \mathrm{mg}$ dengan perdarahan gastrointestinal yang lebih sedikit. Asetosal bekerja sebagai antiplatelet dengan menghambat secara irreversibel siklooksigenase dimana dapat mencegah konversi asam arakhidonat menjadi tromboxan A2 yang merupakan vasokonstriktor kuat agregasi platelet. Dosis efektif aspirin sebagai antiplatelet masih diperdebatkan, terutama karena efeknya pada gastrointestinal, sehingga dosis rendah lebih baik.

Penggunaan obat stroke golongan neuroprotektor yang digunakan adalah pirasetam sebanyak 48 pasien (53,9\%), citicolin sebanyak 8 pasien $(9,0 \%)$, kortikosteroid sebanyak 4 pasien $(4,5 \%)$, calcium channal blocker oral sebanyak 15 pasien $(16,9 \%)$ dan tanpa pemberian neuroprotektor sebanyak 14 pasien $(15,7 \%)$. Tujuan pemberian obat golongan neuroprotektor adalah sebagai perlindungan pada sistem saraf pusat yang mengalami infark. Pirasetam adalah derivat neurotransmiter gamma-aminobutyric acid (GABA) yang mempunyai berbagai efek fisiologi. Pada level nueronal pirasetam memodulasi neurotansmiter pada daerah kolinergik. Pada level vaskular mengurangi adhesi eritrosit pada endotelium vaskular, menghalangi vasospasme, dan memfasilitasi mikrosirkulasi. Golongan kortikosteroid bertujuan untuk menurunkan edema pada otak sehingga meningkatkan aliran darah cerebral pada daerah yang mengalami iskemia. Golongan CCB berperan pada penetrasi ke susunan saraf pusat yang berguna untuk memperkecil kerusakan neurologi yang berhubungan dengan keadaan iskemik (Lovell \& Ernst, 2017).

Kejadian DRP pada pasien stroke di poliklinik rawat jalan RSUD Dr M Yunus Bengkulu terjadi sebesar 31 kasus. Dalam penelitian ini pasien yang tidak mengalami DRP sebanyak 58 pasien. Sebanyak 20 pasien tidak mendapatkan terapi sesuai dengan kondisi klinis pasien. Pasien tidak mendapatkan obat antiplatelet baik asetosal maupun clopidogrel. Antiplatelet adalah obat yang dapat menghambat agregasi trombosit sehingga menyebabkan terhambatnya pembentukan trombus yang terutama sering ditemukan pada sistem arteri. Pemberian antiplatelet bermanfaat untuk mengurangi kekambuhan pada stroke non hemoragik akibat penyumbatan dan kematian akibat gangguan pembuluh darah. Aktivasi dan agregasi trombosit memegang peranan penting dalam pembentukan trombosis arteri yang menyebabkan stroke. Aterosklerosis adalah penyebab paling sering dari penyakit arteri koroner dan penyakit serebrovaskular. Pecahnya plak aterosklerosis dan pembentukan trombus memegang peranan penting dalam perkembangan sindrom stroke. Setelah plak pecah, trombosit memulai sebuah proses kompleks, terdiri dari adhesi, aktivasi, dan agregasi platelet. Hal ini menyebabkan antiagregasi sebagai terapi dalam stroke (Dinata dkk., 2013).

Pada kejadian ada obat yang tidak diperlukan terdapat 3 pasien yang mendapatkan obat yang tidak sesuai dengan kondisi klinis. Pasien mendapatkan NSAID, yaitu meloxicam dan tramadol. Berdasarkan hasil wawancara, pasien tidak mempunyai keluhan nyeri. Menurut kriteria Beer's NSAID tidak direkomedasikan untuk pasien geriatri karena berisko perdarahan gastrointestinal, memperburuk edema, dan melukai ginjal pada stadium lanjut. Kejadian DRP selanjutnya yang terjadi pada kategori efek samping obat. Berdasarkan hasil penelitian terdapat 4 pasien yang mengalami efek samping obat. Efek samping obat terjadi pada penggunaan obat antiplatelet yaitu asetosal. Salah satu efek samping asetosal adalah rasa tidak enak diperut, mual dan perdarahan saluran cerna. Penggunan bersama antasida atau reseptor antagonis $\mathrm{H}_{2}$ bloker seperti ranitidin dapat mengurangi efek samping tersebut. Pada kategori pemilihan obat tidak tepat terjadi pada 4 pasien yang mendapat obat natrium diklofenak. Natrium diklofenak termasuk ke dalam golongan obat NSAIDs atau Non Steroid Anti Inflamation Drugs merupakan salah satu obat yang sering digunakan dalam mengatasi inflamasi dan nyeri (Lanza dkk., 2009). NSAIDs bekerja dengan cara 
menghambat enzim cyclooxygenase-1 dan 2 (COX-1 dan COX-2) sehingga menurunkan produksi prostaglandin (PGE2) dan protasiklin (PGI2) yang merupakan mediator inflamsi sehingga mengakibatkan terjadinya vasokonstriksi. Selain mengakibatkan vasokonstriksi, penghambatan produksi prostaglandin ini berefek pada meningkatnya retensi natrium (Lovell \& Ernst, 2017). Berdasarkan mekanisme tersebut maka penggunaan NSAIDs ini dapat berakibat pada timbulnya beberapa komplikasi seperti hipertensi, edema, dan gangguan fungsi ginjal (Landefeld dkk., 2016; Lovell \& Ernst, 2017).

Pada pasien hipertensi, tekanan darah akan meningkat $\geq 140 / 90 \mathrm{mmHg}$ secara persisten (Soenarta dkk., 2015). Namun NSAIDs dengan mekanismenya sebagai obat antiinflamasi juga berdampak pada peningkatan tekanan darah (Landefeld dkk., 2016; Lovell \& Ernst, 2017). Sehingga akan menjadi suatu masalah ketika pasien dengan riwayat hipertensi mengkonsumsi NSAIDs.

Berdasarkan hasil analisis menunjukkan bahwa faktor usia tidak berhubungan dengan kejadian DRP, yang ditunjukkan dengan nilai $p=0,377$. Kategori usia geriatri tidak menunjukkan adanya peningkatan risiko kejadian DRP dibandingkan dengan pasien non geriatri. Faktor risiko selanjutnya adalah jumlah obat yang diterima pasien. Hasil menunjukkan jumlah obat yang diterima pasien tidak berhubungan dengan kejadian DRP ditunjukkan dengan nilai signifikansi 0,472. Pasien yang menerima obat lebih dari 3 macam tidak menunjukkan adanya peningkatan risiko kejadian DRP dibandingkan dengan pasien yang menerima obat kurang dari 3 macam.

Berdasarkan hasil analisis menunjukkan bahwa keadaan fisik memberikan hasil yang berbeda signifikan $(\mathrm{p}<0,05)$ terhadap drug related problems (DRP's). Skor keadaan fisik yang rendah menggambarkan bahwa pasien masih megalami keterbatasan dan kesulitan saat menjalani aktivitas fisik mereka (Kong \& Yang, 2006). Setelah mengalami serangan stroke berulang, pasien memiliki kecenderungan untuk lebih mengalami ketidakmampuan dan kecacatan fisik dibandingkan dengan serangan stroke pertama (Coull \& Rothwell, 2004; Samsa dkk., 1999; Samuelsson dkk., 1996). Adanya kecenderungan tersebut mengindikasikan pentingnya prognosis, rencana terapi, dan rehabilitasi yang tepat agar tidak menimbulkan masalah dalam pengobatan yang akhirnya memicu munculnya kejadian drug related problems (DRP) (Sien Ng dkk., 2007).

\section{KESIMPULAN}

Jenis stroke yang paling banyak terjadi di RSUD Dr M Yunus Bengkulu adala stroke non hemoragik sebanyak 85 pasien $(95,5 \%)$. Kejadian drug related problems (DRP's) pada pasien stroke di poliklinik rawat jalan RSUD Dr M Yunus Bengkulu terjadi sebesar 31 kasus. Jenis drug related problems (DRP's) yang terjadi meliputi ada indikasi yang tidak diterapi sebanyak 20 kasus $(22,5 \%)$, ada obat yang tidak perlu sebanyak 3 kasus $(3,4 \%)$, efek samping obat sebanyak 4 kasus $(4,5 \%)$, dan pemilihan obat yang tidak tepat sebanyak 4 kasus $(4,5 \%)$. Tidak ada hubungan antara faktor risiko umur dan jumlah obat yang diterima pasien dengan kejadian drug related problems (DRP's). Terdapat hubungan antara kualitas hidup pasien stroke dengan drug related problems (DRP's) pada domain keadaan fisik.

\section{DAFTAR PUSTAKA}

Besdine, R. W., Beers, M. H., Bootman, J. L., Fulmer, T. T., Gerbino, P., Manasse, H. R. \& Wykle, M. L. (2003). When Medicine Hurts Instead of Helps: Preventing Medication Problems in Older Persons by Aging Research. http://www.angingresearch.org. Accessed: 28 September 2014.

Brizendine, L. (2006). The Female Brain. Jakarta: Ufuk Press.

Chobanian, A. V., Bakris, G. L., Black, H. R., Cushman, W. C., Green, L. A., Izzo, J. L. Jr, Jones, D. W., Materson, B. J., Oparil, S., Wright, J. T. Jr \& Roccella, E. J. (2004). The Seventh Report of the Joint National Committee on Prevention, Detection, Evaluation, and Treatment of High Blood Pressure: the JNC 7 report. The Journal of the American Medical Association; 289; 2560-2572.

Coull A. J. \& Rothwell P. M. (2004). Underestimation of Early Risk of Recurrent Stroke: Evidence of the Need for a Standard Definition. Stroke; 35; 1925-1929.

Dinata, C. A., Saftrita Y. \& Sastri, S. (2013). Gambaran Faktor Risiko dan Tipe Stroke pada Pasien Rawat Inap di Bagian Penyakit dalam RSUD Kabupaten Solok Selatan Periode 1 Januari - 31 Juni 2010. Jurnal Kesehatan Andalas; 2; 57-61.

Fagan, S. C. \& Hess, D. C. (2005). Pharmacotherapy: A Pathophysiologic Approach, sixth edition. Columbus: The McGraw-Hill Companies. 
Goldstein, L. B., Adams, R., Alberts, M. J., Appel, L. J., Brass, L. M., Bushnell, C. D., Culebras, A., DeGraba, T. J., Gorelick, P. B., Guyton, J. R., Hart, R. G. \& Howard, G. (2006). Primary Prevention of Ischemic Stroke: A Guideline from the America Heart Association/America Stroke Association Stroke Council: Cosponsered by the Atheroslecotic Peripheral Vascular Disease Interdisciplinary Working Group; Cardiovascular Nursing Council; Clinical Cardiology Council; Nutrition, Physical Activity, and Metabolism Council; and the Quality of Care and Outcomes Research Interdisciplinary Working Group: the American Academy of Neurology Affirms the Value of This Guideline. Stroke; 37; 1583-1633.

Indriani, R. (2014). Jumlah Pria Perokok di Indonesia Kedua Tertinggi di Dunia by Ririn Indriani (Berita Satu). http://www.beritasatu.com/kesehatan/159720jumlah-pria-perokok-di-indonesia-keduatertinggi-di-dunia.html. Accessed: 13 September 2018

Kong, K. H. \& Yang, S. Y. (2006). Health-related Quality of Life Among Chronic Stroke Survivors Attending a Rehabilitation Clinic. Singapore Medical Journal; 47; 213.

Landefeld, K., Gonzales, H., \& Sander, G. (2016). Hypertensive Crisis: The Causative Effects of Nonsteroidal Anti-Inflammatory Drugs. Journal of Clinical Case Reports; 6; 1-3.

Lanza, F., Chan, F., \& Quigley, E. (2009). Guideline for Prevention of NSAID-Related Ulcer Compliction. The American Journal of Gastroenterologi; 104; 728-738.

Lovell, A. \& Ernst, M. (2017). Drug Induces Hypertension: Focus on Mechanisms and Management. Current Hypertension Reports, 19; $1-12$.
Perwitasari, D. A., Atthobari, J., Dwiprahasto, I., Hakimi, M., Gelderblom, H., Putter, H., Nortier, J. W. R., Guchelaar, H. \& Kaptein, A. A. (2010). Translation and Validation of EORTC QLQ-C 30 Into Indonesian Version for Cancer Patients in Indonesia. Japanese Journal of Clinical Oncology; 41; 519-529.

Rahajeng, B. (2007). Drug Realted Problems pada Penatalaksanaan Pasien Stroke Rawat Inap di RSAL Dr Ramelan Surabaya Periode 1 September - 31 Oktober 2006. Tesis; Sekolah Pascasarjana Universitas Gadjah Mada, Yogyakarta.

Samsa, G. P., Bian J., Lipscomb, J., \& Matchar, D. B. (1999). Epidemiology of Recurrent Strokes on 2-year Survival and Cost. Stroke; 30; 338-349.

Samuelsson, M., Soderfeldt, B., Olsson, G. B. (1996). Functional Outcome in Patients with Lacunar Infraction. Stroke; 27; 842-846.

Sien Ng, Y., Jung, H., Chiong, Y. \& Lim P. A. (2007). Do Recurrent Stroke Patients Have Poorer Functional Outcomes Compared with First-Time Stroke Patients After Inpatient Rehabilitation. Physical Medicine and Rehabilitation; 88; 105.

Soenarta, A., Erwinanto., Mumpuni A., Barack R., Lukito A., Hersunarti N., Pratikto R. (2015). Pedoman Tatalaksana Hipertensi pada Penyakit Kardiovaskuler. Surabaya: Perhimpunan Dokter Spesialis Kardiovaskuler Indonesia.

Yuliana, A., Arifin, H., Darwin, D. \& Raveinal. (2011). Analisa Drug Related Problems pada Pasien Dislipidemia di Bangsal Rawat Inap dan Rawat Jalan Penyakit dalam RSUP Dr. M. Djamil Padang. Jurnal Sains dan Teknologi Farmasi; 16; 197-202.

Yunaidi, Y. (2010). Intervensi pada Stroke Non Hemoragik. Jurnal Kardiologi Indonesia; 31; 153-155. 